\title{
Calix[4]pyrrole macrocycle: Extraction of fluoride anions from aqueous media
}

\author{
Ismail Ibrahim Abbas*, Hassan Hasan Hammud and Hasan Shamsaldeen \\ Department of Chemistry, Faculty of Science, Beirut Arab University, Beirut, 115020, Lebanon \\ ${ }^{*}$ Corresponding author at: Department of Chemistry, Faculty of Science, Beirut Arab University, Beirut, 115020, Lebanon. \\ Tel.: +961.3.601140; fax:+961.1.818402.E-mail address: ismaabbas@hotmail.com (I.I. Abbas).
}

\section{ARTICLE INFORMATION}

Received: 01 November 2011

Received in revised form: 03 January 2012

Accepted: 04 January 2012

Online: 30 June 2012

\section{KEYWORDS}

\section{Langmuir}

Freundlich

Extraction

Fluoride anion

Calix[4]pyrrole

Dubbin-Redushkevich isotherm

\begin{abstract}
Solid-phase extraction of fluoride anions by calixpyrrole macrocycle (CP) from aqueous media has been studied using the batch method. Various significant extraction parameters like initial concentration of the anion, extraction time, concentration of the calixpyrrole, $\mathrm{pH}$ and temperature were evaluated. Langmuir, Freundlichand, Dubinin-Redushkevish (D-R) isotherms and coefficients were used to analyze the equilibrium data. The amount of fluoride anion extracted per unit of the $\mathrm{CP}$ was found to be $0.40 \mathrm{mg} / \mathrm{g}$ at $298 \mathrm{~K}$ from $19 \mathrm{mg} / \mathrm{L}$ aqueous solution of fluoride anions. The mean free energy calculated from D-R model for the removal of fluoride anions by the CP was found to be $10.0 \mathrm{~kJ} / \mathrm{mol}$, indicating that chemisorption is involved in the extraction process. The data were also fitted to kinetic models such as pseudo first order and pseudo second order. The removal of fluoride anions increased with increasing temperature indicating the endothermic nature of the extraction process. The present method has been compared with the previous methods.
\end{abstract}

\section{Introduction}

[20-22] which are one of the more recent additions to the assortment of macrocycles. Calix[4]pyrroles are known for their anion binding properties as these are able to make hydrogen bonds through the pyrrolic - $\mathrm{NH}$ - group [23]. Thermodynamic investigations involving calixpyrrole and anions have demonstrated the selectivity of this ligand for the fluoride anion among the halides in solution $[11,12]$. Recently, Sessler et al. have developed the first polymeric systems containing a calixpyrrole anion receptor directly appended to a polymeric backbone which could be readily optimized for use in a range of ion-binding and extraction applications [24].

The availability of an inexpensive and cheaply synthesized material with high selectivity further enhanced our interest in choosing calixpyrrole for removal of fluoride anions from aqueous media. Despite that calix[4]pyrrole has found a considerable number of applications (ion selective electrodes, as anchor groups in solid supports for anion separation by high performance liquid chromatography, optical sensors) [25-28]. Its potential for the removal of fluoride anions from water is still unexplored. In this paper the calix[4]pyrrole ligand is used for the selective removal of fluoride from water. The capacities of calixpyrrole to remove $\mathrm{F}$ - anions from aqueous solutions are compared with those previously reported in literature.

\section{Experimental}

\subsection{Chemicals}

Pyrrole (98\%), ethanol (HPLC grade) and acetone (HPLC grade) were all purchased from Aldrich and used as received. Hydrochloric acid, sodium fluoride (99\%), sodium chloride, sodium hydroxide and calcium chloride were purchased from Fisher Scientific, UK. The deuterated chloroform $\left(\mathrm{CD}_{3} \mathrm{Cl}\right)$ and tetramethylsilane (TMS) were purchased from Aldrich, UK. complexation with the receptor, allowing the translocation of the guest through media it would not normally be able to pass through. These requirements are fulfilled by calix[4]pyrroles 


\subsection{Preparation of calix[4]pyrrole}

The preparation of calixpyrrole (Scheme 1) was achieved by following the procedure reported in the literature [23]. ${ }^{1} \mathrm{H}$ NMR (300 MHz, $\left.\mathrm{CDCl}_{3}, \delta, \mathrm{ppm}\right): 7.40(\mathrm{~s}, 1 \mathrm{H}, \mathrm{NH}), 5.80(\mathrm{~d}, 2 \mathrm{H}$, $\mathrm{PyH}, J=2.7 \mathrm{~Hz}), 1.48\left(\mathrm{~s}, 6 \mathrm{H}, \mathrm{CH}_{3}\right) \cdot{ }^{13} \mathrm{C} \mathrm{NMR}\left(300 \mathrm{MHz}, \mathrm{CDCl}_{3}, \delta\right.$,

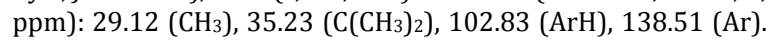
Anal. calcd. for $\mathrm{C}_{28} \mathrm{H}_{36} \mathrm{~N}_{4}$ : C, 78.46, H, 8.47, N, 13.07. Found: C, 78.46, H, 8.58, N, 13.13\%.

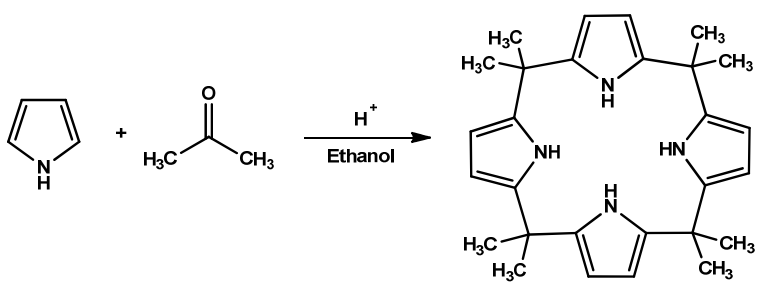

Scheme 1

\subsection{Analytical determination of fluoride and chloride anions} in aqueous solution

Stock solutions of fluoride and chloride salts were prepared ( $1000 \mathrm{mg} / \mathrm{L}$ ) by dissolving accurate amounts of $\mathrm{NaF}$ and $\mathrm{NaCl}$ respectively in double distilled water. The analysis of anion in the aqueous phase was performed by using Fluoride and Chloride Ion Selective Electrodes (ELIT 8221). The electrodes were calibrated for 1,10 and $100 \mathrm{mg} / \mathrm{L}$ fluoride and chloride solutions using the total ionic strength absorbing buffer (TISAB) [29]. The calibrated electrodes were used for measuring fluoride and chloride concentrations of water samples.

\subsection{Effect of calixpyrrole dose}

For these experiments, different quantities (0.01-2.50 g) of calixpyrrole material were weighed and added to a set of eight test tubes, each one containing $10 \mathrm{~mL}$ of the same concentration (19 ppm) of a given solution of fluoride anion prepared in deionized water. The tubes were then shaken on a rotamixer for $5 \mathrm{~min}$ to ensure homogenous mixing, sealed and then left overnight in a thermostated water bath at $25^{\circ} \mathrm{C}$. After equilibrium was attained, the solutions were filtered through $0.45 \mu \mathrm{m}$ Millipore filters (Type HA) and filtrates were analyzed for F- anion concentrations.

\subsection{Uptake capacity of calixpyrrole}

Fluoride uptake capacities of the calixpyrrole ligand were determined under static conditions by the batch equilibrium technique. An optimum mass of the solid phase $(1.0 \mathrm{~g})$ was added to a $10 \mathrm{~mL}$ of anion salt solutions of different concentrations $(0.19-190 \mathrm{ppm})$. The mixtures were mechanically shaken for 5 min to reach equilibrium. The tubes were then placed in a water bath and the temperature was maintained at $25^{\circ} \mathrm{C}$. After the equilibrium was attained, anions were then analyzed by the Fluoride ISE. The amount of anions removed was calculated from the difference in their initial and final concentrations in the aqueous solutions.

The kinetics of the extraction process as well as the effect of $\mathrm{pH}$, salt concentration and temperature on the extraction process was determined.

\subsubsection{Effect of the solution $\mathrm{pH}$}

The efficiency of the calixpyrrole material to extract fluoride anions was investigated in the $2-12 \mathrm{pH}$ range under static conditions. The concentration of the initial ion salt $(19$ ppm) was kept constant in aqueous solution whilst the solution
$\mathrm{pH}$ was adjusted to the desired values by addition of either sulfuric acid or sodium hydroxide.

\subsubsection{Effect of contact time}

The ability of the macrocycle to uptake fluoride ions was examined under the same batch conditions, but at different time intervals $(5,10,15,20,25$ and $30 \mathrm{~min})$ where the solution was kept at the $\mathrm{pH}$ at which there is the highest fluoride ion uptake by this ligand.

\subsubsection{Effect of temperature}

To investigate the temperature effects on the extraction ability of calixpyrrole ligand, a fixed amount of the solid phase material was equilibrated with a volume $(10 \mathrm{~mL})$ of the fluoride ion salt solution (19 ppm) at different temperatures (5, $10,25,35$ and $41^{\circ} \mathrm{C}$ ). The phases were separated and the concentrations of fluoride ion salts in the aqueous phase were determined.

\section{Results and discussion}

\subsection{Effect of calixpyrrole dose}

Danil de Namor has previously demonstrated (through ${ }^{1} \mathrm{H}$ NMR, conductance and calorimetric measurements) that calixpyrrole forms a 1:1 complex with fluoride anion via $\mathrm{H}$ bond formation with the NH groups of this ligand [11]. The selectivity trend for this ligand for anions was established to be as follows: $\mathrm{F}->\mathrm{H}_{2} \mathrm{PO}_{4}>\mathrm{Cl}->\mathrm{Br}$.

Given that calixpyrrole is completely insoluble in water [11], the ligand was used in solid-phase removal of fluoride anions from aqueous media. The effect of the amount of calixpyrrole used to explore the retention properties of calixpyrrole has been studied by varying the amount of material and keeping other parameters $(\mathrm{pH}$, temperature, contact time, and the initial concentration of anion (19 ppm)) constant (Figure 1). It can be observed that the uptake capability of the calixpyrrole generally improved by increasing its amount in $\mathrm{F}^{-}$solution. This is expected due to the fact that the higher amount of material in the solution means greater availability of binding sites ( $\mathrm{NH}$ groups) for fluoride ions.

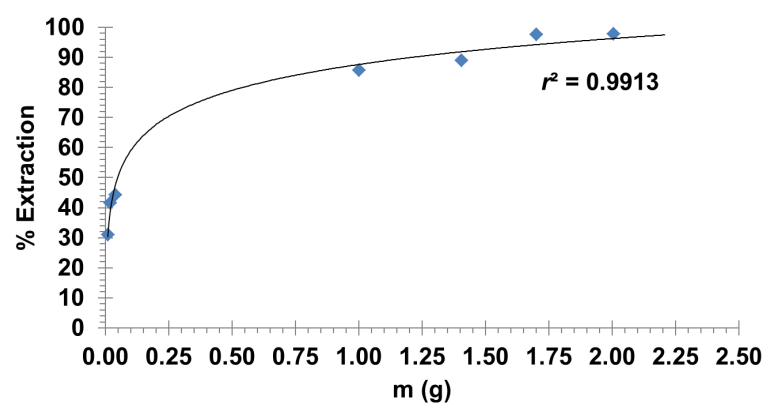

Figure 1. Effect of the amount of calixpyrrole on the percentage extraction of $\mathrm{F}$ - anions from aqueous media at $25^{\circ} \mathrm{C}$.

It was observed that at a given solid/solution ratio (100 $\mathrm{g} / \mathrm{L}$ ) no further uptake of $\mathrm{F}^{-}$ions from aqueous solution was obtained. The maximum percentage of fluoride anions removed at $100 \mathrm{~g} / \mathrm{L}$ solid/solution ratio was found to be $86 \%$. On the other hand only $30 \%$ of chloride anions $\left(\mathrm{Na}^{+}\right.$as counter ion) were removed using the same solid/solution ratio. This indicates that calixpyrrole can preferentially interact with $\mathrm{F}^{-}$ anions relative to $\mathrm{Cl}$. The calixpyrrole-fluoride complex was isolated after extraction and microanalysis was carried out. Anal. calcd. for the salt $\mathrm{C}_{28} \mathrm{H}_{36} \mathrm{FN}_{4} \mathrm{Na}$ : C, 71.46; $\mathrm{H}, 7.71 ; \mathrm{N}, 11.91$. Found: C, 71.37; H, 7.71; N, 11.91\%. 


\subsection{Fluoride anion uptake isotherms}

In order to understand the uptake capacity of the system, it is important to perform the equilibrium curves. In the present study, three adsorption isotherms namely the Langmuir, Freundlich and Dubinin-Redushkevich (D-R) were used to describe the obtained equilibrium data.

The equilibrium experimental data were correlated with Langmuir (Equation 1) and Freundlich (Equation 2) isotherm models.

$$
\frac{\mathrm{C}_{\mathrm{e}}}{\mathrm{q}_{\mathrm{e}}}=\frac{1}{\mathrm{bq}_{\mathrm{m}}}+\frac{\mathrm{C}_{\mathrm{e}}}{\mathrm{q}_{\mathrm{m}}}
$$

In equation $1, \mathrm{C}_{e}$ is the equilibrium concentration $(\mathrm{mmol} / \mathrm{L}), \mathrm{q}_{\mathrm{e}}$ is the amount of anion uptake at equilibrium time (mmol/g), and $\mathrm{q}_{\mathrm{m}}$ and $\mathrm{b}$ are Langmuir constants related to the uptake capacity and energy respectively.

The Freundlich adsorption isotherm is represented by the equation 2 .

$$
\log q_{e}=\log k+\frac{1}{n} \log C_{e}
$$

where $k$ and $n$ are Freundlich constants. An indication of the favorability given by $n$ and $k$ denotes the capacity of the material.

The Langmuir and Freundlich isotherms do not give any idea about mechanism of extraction. Therefore, the equilibrium data were tested with Dubinin-Redushkevich isotherm model [30] to distinguish between the physical and chemical uptake of fluoride anions by the calixpyrrole. The linear form of D-R isotherm is represented by the equation 3 .

$$
\ln q_{e}=\ln q_{m}-\beta \varepsilon^{2}
$$

where $q_{e}$ is the equilibrium concentration of anion (mol/g), $q_{m}$ is the maximum uptake capacity $(\mathrm{mol} / \mathrm{g}), \beta$ is the activity coefficient related to the mean free energy of adsorption $\left(\mathrm{mol}^{2} \mathrm{~J}^{2}\right)$ and $\varepsilon$ is Polanyi potential. The value of $\varepsilon$ can be calculated from the equation 4 .

$\varepsilon=R T \ln \left(1+\frac{1}{C_{e}}\right)$

where $R$ is the universal gas constant $(\mathrm{J} / \mathrm{mol}), T$ is the absolute temperature in Kelvin and $C_{e}$ is the equilibrium anion concentration in the solution $(\mathrm{mmol} / \mathrm{L})$.

The activity coefficient $b$ was further used to calculate the adsorption mean free energy (E; $\mathrm{kJ} / \mathrm{mol}$ ) which is required to transfer the sorbate to the surface of sorbent from infinity in the solution, and the relation can be calculated using the equation 5 .

$$
E=\frac{1}{\sqrt{-2 \beta}}
$$

\subsubsection{Langmuir isotherm}

The Langmuir monolayer capacity (Figure 2) of $0.4 \mathrm{mg} / \mathrm{g}$ is quite large. Figure 3 shows the linear plots of $\mathrm{C}_{\mathrm{e}} / \mathrm{q}_{\mathrm{e}} v s \mathrm{C}_{\mathrm{e}}$, which is an indication of the applicability of Langmuir isotherm for the systems under consideration.

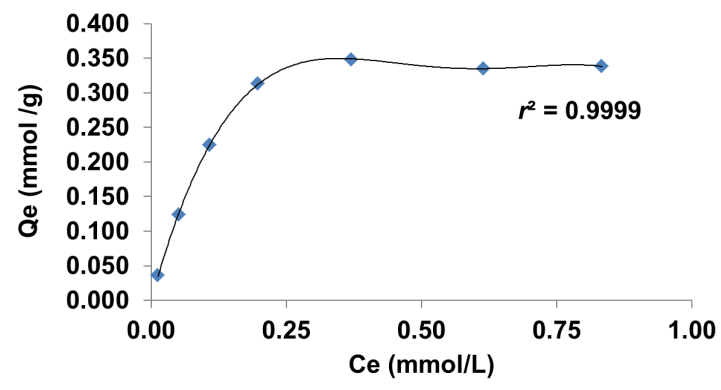

Figure 2. Uptake isotherm for the $\mathrm{F}^{-}$anions from aqueous solution by calixpyrrole at $25^{\circ} \mathrm{C}$.

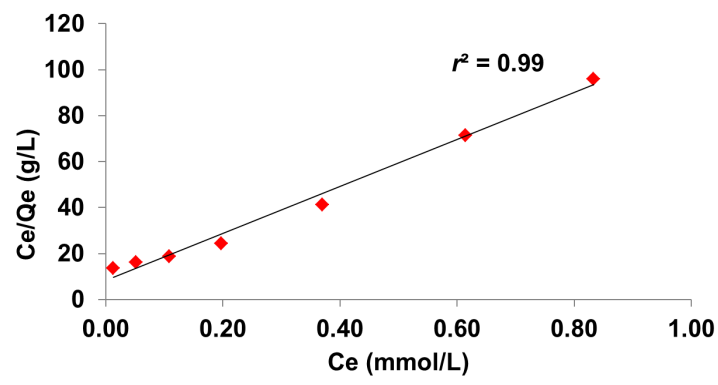

Figure 3. Linearized Langmuir isotherms for F- uptake by the calixpyrrole at $25^{\circ} \mathrm{C}$.

The removal of fluoride anions by the calixpyrrole follows the Langmuir isotherm model. The $\mathrm{q}_{\mathrm{m}}(0.01 \pm 0.001 \mathrm{mmol} / \mathrm{g})$ and $\mathrm{b}(12.08 \mathrm{~L} / \mathrm{mmol})$ values represented in Table 1 are calculated from the slopes and intercepts of the plots. The separation factor $\left(R_{L}=0.99\right)$ also supports the favorable removal of fluoride anions by the calixpyrrole [31].

Generally, the high binding constants $(b=12.03 \mathrm{~L} / \mathrm{mmol})$ listed in Table 1 support the uptake of fluoride anions from the aqueous solution by the solid phase via H-bonding with the $\mathrm{NH}$ donor sites of the ligand. This value indicates a high thermodynamic stability of extraction process in aqueous solution.

\subsubsection{Freundlich isotherm}

The fluoride ion retention also follows the Freundlich relationship (Figure 4). The plot shows good linearity $\left(\mathrm{R}^{2}=\right.$ 0.91). The values of uptake coefficients $(0.016 \pm 0.002$ $\mathrm{mmol} / \mathrm{g}$ ), computed from this plot are given in Table 1 . The correlation coefficient shows that, in general, the Langmiur model $\left(\mathrm{R}^{2}=0.99\right)$ fitted the results slightly better than the Freundlich model $\left(\mathrm{R}^{2}=0.91\right)$. The $1 / \mathrm{n}$ value $(0.59)$ obtained in this study $(0.1<1 / \mathrm{n}<1.0)$ suggests that this material can be used effectively for the removal of the fluoride anion from aqueous solutions.

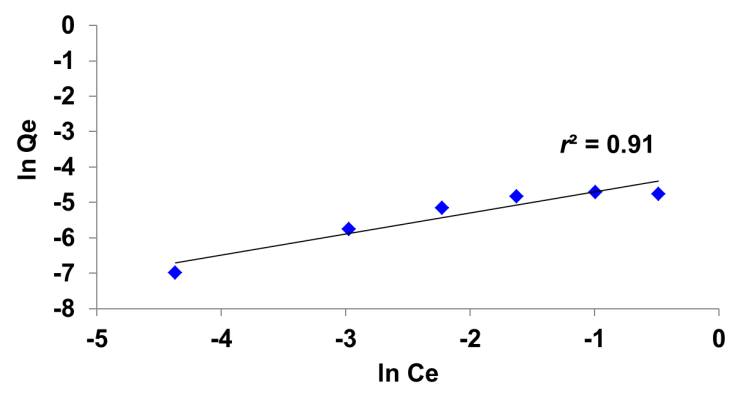

Figure 4. Linearized Freundlich isotherms for F-uptake by the calixpyrrole at $25^{\circ} \mathrm{C}$. 
Table 1. Isotherm constants for the removal of fluoride anions by calixpyrrole at $25^{\circ} \mathrm{C}$.

\begin{tabular}{|c|c|c|c|c|c|c|c|c|c|}
\hline \multicolumn{4}{|l|}{ Langmuir } & \multicolumn{3}{|l|}{ Freundlich } & \multicolumn{3}{|l|}{ D-R } \\
\hline $\mathrm{q}_{\mathrm{m},(\mathrm{mmol} / \mathrm{g})}$ & b, (L/mmol) & $\mathbf{R}^{2}$ & $\mathbf{R}_{\mathbf{L}}$ & $\mathrm{k}(\mathrm{mmol} / \mathrm{g})$ & $\mathbf{n}$ & $\mathbf{R}^{2}$ & $\mathrm{q}_{\mathrm{m}}(\mathrm{mmol} / \mathrm{g})$ & $\mathrm{E},(\mathrm{kJ} / \mathrm{mol})$ & $\mathbf{R}^{2}$ \\
\hline $0.010 \pm 0.001$ & 12.08 & 0.99 & 0.99 & $0.016 \pm 0.002$ & 1.67 & 0.91 & $0.052 \pm 0.001$ & 10 & 0.94 \\
\hline
\end{tabular}

\subsubsection{Dubinin-Redushkevich isotherm}

Plots of $\ln \mathrm{q}_{\mathrm{e}} v s \varepsilon^{2}$ (Figure 5) give a linear relationship with slopes of $\beta$ and intercept of $q_{m}$. The values of $q_{m}(0.052 \pm 0.001$ $\mathrm{mmol} / \mathrm{g})$ and $\mathrm{E}(10 \mathrm{~kJ} / \mathrm{mol})$ are given in Table 1 . The mean free energy gives information about adsorption mechanism whether it is physical or chemical. If $E$ value lies between 8 and $16 \mathrm{~kJ} / \mathrm{mol}$, the process takes place chemically and while $\mathrm{E}<8$ $\mathrm{kJ} / \mathrm{mol}$ the process is of a physical nature [32]. In the present work, the results $(E=10 \mathrm{~kJ} / \mathrm{mol})$ implied that the uptake process is chemical adsorption. This result agrees with ${ }^{1} \mathrm{H}$ NMR studies [11]. The values of $\mathrm{R}^{2}$ provide an indication of how well the experimental data fits with the isotherm models. From Table 1 , it is evident that the Langmuir isotherm model exhibited a better fit to the equilibrium data for the calixpyrrole. Therefore, the uptake process can be interpreted as monolayer adsorption.

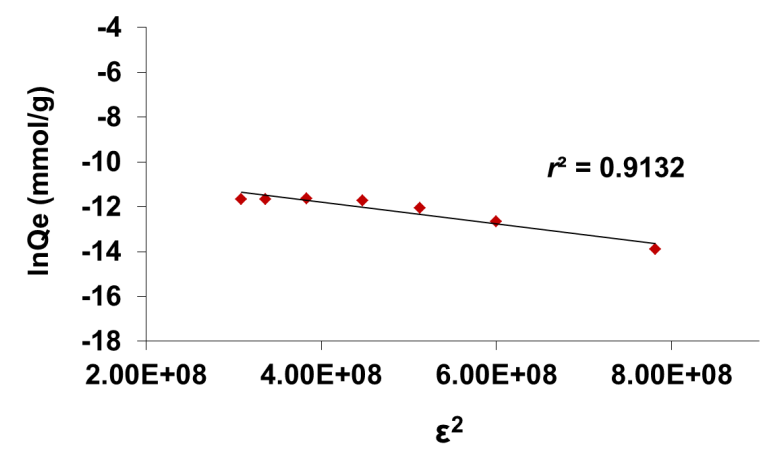

Figure 5. Linearized Dubinin-Redushkevich isotherms for F- uptake by calixpyrrole at $25{ }^{\circ} \mathrm{C}$.

\subsection{Effect of solution $\mathrm{pH}$}

The $\mathrm{pH}$ of the solution is one of the main parameters, which significantly affects the extent of fluoride adsorption, and was controlled by adding sufficient $\mathrm{HCl} / \mathrm{NaOH}$ solution ranging from 2 to 12. The results are shown in Figure 6 in which percentages of extraction (\% E) are plotted against the initial $\mathrm{pH}$ of the solution.

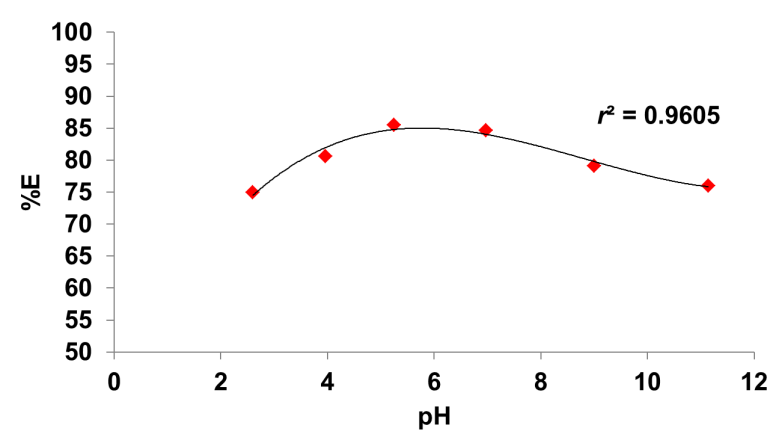

Figure 6. Effect of $\mathrm{pH}$ on the uptake of $\mathrm{F}$ - anion from aqueous solution at 25 ${ }^{\circ} \mathrm{C}$ by the calixpyrrole.

It is worth mentioning that the calixpyrrole was initially prepared under very acidic conditions and is very stable in this medium [23]. During the study of the effect of solution $\mathrm{pH}$, the amount of material used and the concentration of solution (19 ppm) were kept constant. An inspection of Figure 6 shows that the uptake of fluoride anion from aqueous solution is $\mathrm{pH}$ dependent. The adsorption increases up to $\mathrm{pH}=7$ and deceases for higher $\mathrm{pH}$. The lower defluoridation efficiency at $\mathrm{pH}$ below 4 is possibly due to protonation of fluoride. This result could be attributed to the formation of weakly ionised hydrofluoric acid.

As the solution $\mathrm{pH}$ is raised toward a neutral value, the magnitude of Coulombic attractive force reduces as the active sites $(\mathrm{NH})$ become neutral. Subsequently the quantities of fluoride anions retained by calixpyrrole levels off and remain nearly constant between $\mathrm{pH}=5$ and 7 . The progressive decrease of fluoride occurred at $\mathrm{pH}>7$ is mainly due to the competition of hydroxides ions, since both $\mathrm{OH}^{-}$and $\mathrm{F}^{-}$are isoelectronic and have the same charge and similar ionic radii.

\subsection{Effect of temperature}

The removal of $\mathrm{F}^{-}$anions by calixpyrrole as a function of temperature is illustrated in Figure 7. It shows that removal capacity increases with temperature. This implies that the process is endothermic. This increase in capacity is due to the chemical interaction between fluoride anions and calixpyrrole. During the extraction process, there are a number of factors to be considered such as the transfer of anion salt (dependent on counter-ion) from aqueous to solid phase as well as the affinity of the active sites of the material for that particular ion. Therefore, the variation in extraction with temperature must be attributed to either or both processes [31].

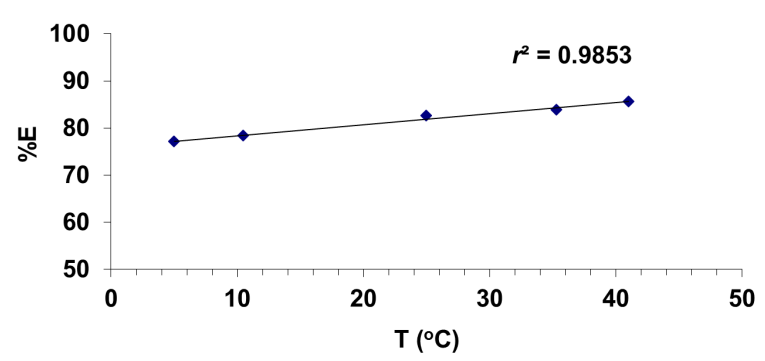

Figure 7. Effect of temperature on the uptake of $\mathrm{F}^{-}$anion from aqueous solution by the calixpyrrole.

The adsorption equilibrium data obtained for different temperatures were used to calculate the important thermodynamic properties such as standard Gibbs free energy $\left(\Delta G^{\circ}\right)$, standard enthalpy change $\left(\Delta H^{\circ}\right)$ and standard entropy change $\left(\Delta S^{\circ}\right)$ [33]. The standard Gibbs free energy was evaluated by

$\Delta G=-R T \ln K_{c}$

The equilibrium constant $K_{\mathrm{c}}$ was calculated using the relationship

$K_{c}=\frac{\left[F^{-}\right]_{\text {extracted }}}{\left[F^{-}\right]_{\text {remained }}}$

The standard enthalpy $\left(\Delta H^{\circ}\right)$ and entropy $\left(\Delta S^{\circ}\right)$ of adsorption were determined from the Van't Hoff equation, 


$$
\ln K_{c}=\frac{\Delta S^{o}}{R}-\frac{\Delta H^{o}}{R T}
$$

where, $\Delta H^{\circ}$ and $\Delta S^{\circ}$ were obtained from the slope and intercept of the Van't Hoff's plot of $\ln K_{\mathrm{c}}$ versus $1 / \mathrm{T}$ as shown in Figure 8.

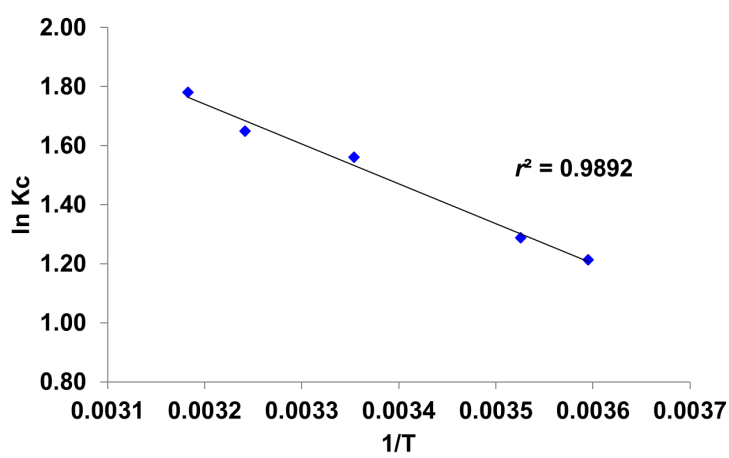

Figure 8. Van't Hoff plot for calixpyrrole.

The thermodynamic parameters at different temperatures are listed in Table 2 . The negative values of $\Delta \mathrm{G}^{\circ}$ reveal that the uptake is feasible and spontaneous. The values become more negative with increase in temperature.

Table 2. Thermodynamic parameters for the removal of fluoride anions by the calixpyrrole.

\begin{tabular}{llll}
$\mathbf{T}(\mathbf{K})$ & $\boldsymbol{\Delta G}^{\mathbf{o}}(\mathbf{k J} / \mathbf{m o l})$ & $\boldsymbol{\Delta H}^{\mathbf{o}}(\mathbf{k J} / \mathbf{m o l})$ & $\boldsymbol{\Delta S}^{\mathbf{o}}(\mathbf{k J} / \mathbf{m o l} . \mathbf{K})$ \\
\hline 278 & $-3.00 \pm 0.07$ & $11.21 \pm 0.14$ & $0.05 \pm 0.01$ \\
284 & $-3.19 \pm 0.12$ & & \\
298 & $-3.89 \pm 0.11$ & & \\
309 & $-4.08 \pm 0.02$ & & \\
314 & $-4.41 \pm 0.15$ & & \\
\hline
\end{tabular}

The positive values of $\Delta H^{\circ}(11.21 \pm 0.14 \mathrm{~kJ} / \mathrm{mol})$ indicate that the adsorption process is endothermic in nature and the positive $\Delta S^{\circ}(0.05 \pm 0.01 \mathrm{~kJ} / \mathrm{mol} \mathrm{K})$ suggests an increased randomness at the solid-liquid interface during the removal of $\mathrm{F}$ - anions using the calixpyrrole. During the extraction of fluoride anions, the solvent molecules, which are displaced by the F-anions, gain more translational entropy than is lost by the anions, thus allowing for the prevalence of randomness in the system [34].

\subsection{Kinetic studies}

The effect of time on the removal of fluoride anions from aqueous solution was investigated by determining the percentage of extraction of the $\mathrm{F}^{-}$anion salt at different time intervals (5-30 min). Other parameters such as the amount of the material, and the solution $\mathrm{pH}$ were kept optimum, while the temperature was kept at $25{ }^{\circ} \mathrm{C}$. The outcome of these experiments is shown in Figure 9 in which percentages of extraction (\% E) are plotted against the contact time. The results indicate that the \%E increases with an increase in the contact time before equilibrium is reached. It can be seen that the removal of the F- anions by the calixpyrrole increases from $40 \%$ to $87 \%$ when the contact time was increased from 5 to 10 min. Optimum contact time for the calixpyrrole was found to be $10 \mathrm{~min}$. Therefore, the kinetics of the extraction process of fluoride anions by the calixpyrrole receptor is fast. The availability of many $\mathrm{NH}$ functional groups, required for interaction with the fluoride anion, significantly improved the binding capacity and the kinetics of the extraction process. This result is an important aspect to consider in wastewater treatment.

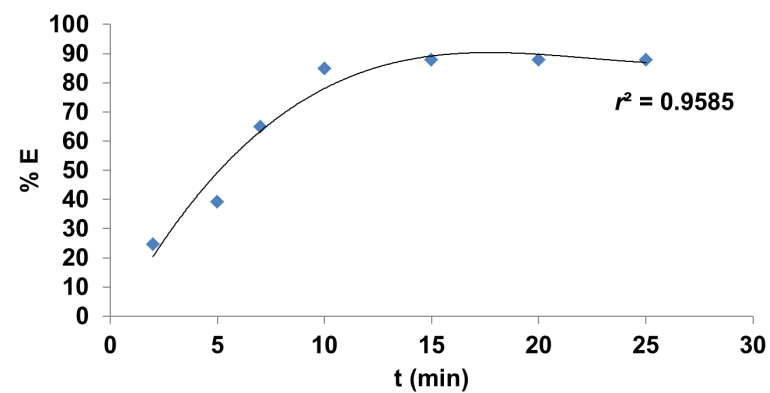

Figure 9. Optimum time for the uptake of F- anions from aqueous solution at $25^{\circ} \mathrm{C}$ by the calixpyrrole.

The kinetic studies describe the rate of removal of fluoride ions and this rate controls the equilibrium time. The kinetics of removal of the F- anions by the calixpyrrole were analyzed by pseudo first order and pseudo second order models.

\section{i. Pseudo first order model}

The adsorption data were fitted to the Lagergren's pseudo first order rate equation [35]

$\frac{d q_{t}}{d t}=K_{1}\left(q_{e}-q_{t}\right)$

On integration from $\mathrm{q}_{\mathrm{t}}=0$ at $\mathrm{t}=0$, gives

$\ln \left(q_{e}-q_{t}\right)=\ln \left(q_{e}-K_{1} t\right)$

where $\mathrm{q}_{\mathrm{e}}$ and $\mathrm{q}_{\mathrm{t}}$ refer to the amount of $\mathrm{F}^{-}$anion adsorbed per unit weight of calixpyrrole $(\mathrm{mg} / \mathrm{g})$ at equilibrium and at any time $\mathrm{t}(\mathrm{min})$. The value of $\mathrm{q}_{\mathrm{e}}$ and first order adsorption rate constant $\mathrm{K}_{1}\left(\mathrm{~min}^{-1}\right)$ can be obtained from the plot of $\ln \left(\mathrm{q}_{\mathrm{e}}-\mathrm{q}_{\mathrm{t}}\right)$ vs $\mathrm{t}$.

\section{ii. Pseudo second order model}

It can be given as [36].

$\frac{d q_{t}}{d t}=K_{2}\left(q_{e}-q_{t}\right)^{2}$

Separating the variables and integrating; where $\mathrm{q}_{\mathrm{t}}=0$ at $\mathrm{t}=$ 0 and $\mathrm{q}_{\mathrm{t}}=\mathrm{q}_{\mathrm{t}}$ at $\mathrm{t}=\mathrm{t}$, gives

$$
\frac{t}{q_{t}}=\left[\frac{1}{K_{2} q_{e}^{2}}+\frac{t}{q_{e}}\right]
$$

The product $K_{2} q_{e}^{2}$ is the initial sorption rate. A plot of $\mathrm{t} / \mathrm{q}$ against $\mathrm{t}$ at different temperatures provides second order adsorption rate constants $\mathrm{K}_{2}(0.910 \pm 0.13 \mathrm{~g} / \mathrm{mg}$.min $)$ and $\mathrm{q}_{\mathrm{e}}$ values from the slopes and intercepts.

The applicability of the models mentioned above was checked by attempting to obtain a linear fit of the experimental data by the appropriate equations. Kinetic constants along with their regression coefficient data for fluoride removal using calixpyrrole are given in Table 3. 
Table 3. Kinetic constants for the removal of fluoride anions by calixpyrrole at $25^{\circ} \mathrm{C}$. Pseudo first order model $\underline{\mathrm{K}_{\mathbf{1}}(\mathbf{1} / \mathbf{m i n})}$ $0.573 \pm 0.11$

$\mathrm{q}_{\mathrm{e}}(\mathrm{mg} / \mathrm{g})$

$\mathbf{R}^{2}$

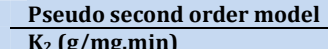
$\mathbf{K}_{\mathbf{2}}$ (g/mg.min) $0.910 \pm 0.13$

Table 4. Comparison of calixpyrrole with some reported sorbents for fluoride anions.

\section{Material}

Calixpyrrole

Polyaniline

Plaster of Paris

Polypyrrole

Zirconium impregnated coconut shell carbon

Lanthanum-modified chitosan

Magnetic chitosan

$\mathrm{MgO}$

Modified Amberlite resin

Amberlitethio-urea resin

$p$-Tetrathioureacalix[4]arene-based resins based resin

$p$-Tetraaminocalix[4]arene based resin

The experimental $\mathrm{q}_{\mathrm{e}}$ values were compared with $\mathrm{q}_{\mathrm{e}}$ values determined by the pseudo first order kinetic model (Figure 10) and the pseudo second order kinetic model (Figure 11).

The pseudo first order model did not apply throughout the contact times. The calculated $\mathrm{q}_{\mathrm{e}}$ values are higher than the experimental value. The $\mathrm{q}_{\mathrm{e}}$ values calculated from the pseudo second order kinetic model are in good agreement with the experimental $\mathrm{q}_{\mathrm{e}}$ values. Thus, the adsorption process obeys the pseudo second order kinetic model. The correlation coefficient $\left(R^{2}\right)$ for this model is high $\left(R^{2}=0.97\right)$ which also confirms that the adsorption phenomena follows second order kinetics.

The pseudo second order model is based on the assumption that the rate-limiting step is a chemical sorption between the fluoride anion and the calixpyrrole. This provides the best correlation of the data.

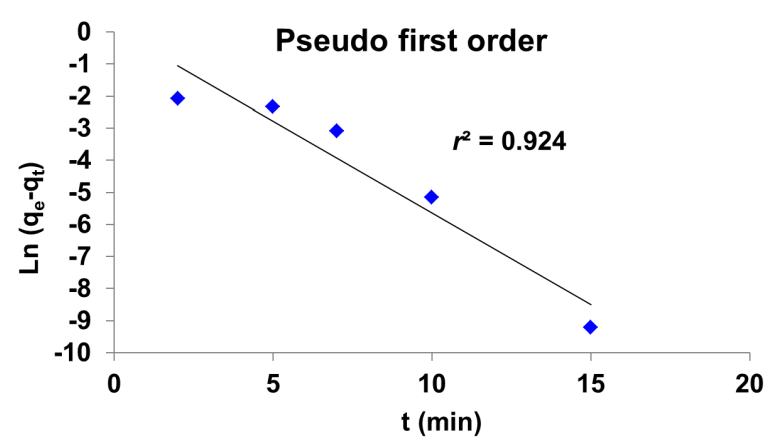

Figure 10. Pseudo first order kinetic plot for the sorption of fluoride anions by the calixpyrrole.

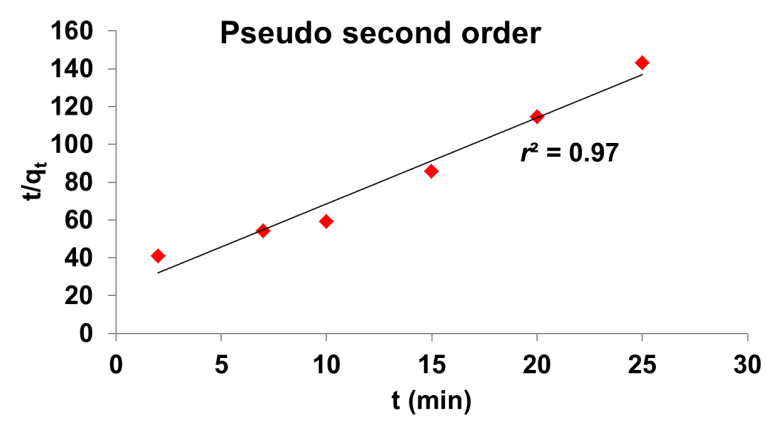

Figure 11. Pseudo second order kinetic plot for the sorption of fluoride anions by the calixpyrrole.

\section{Comparison with alternative materials}

Although direct comparison of the calixpyrrole with other materials [36-41] is difficult owing to the different applied experimental conditions, it was found, in general, that the removal capacity of the calixpyrrole $(0.4 \mathrm{mg} / \mathrm{g})$ for fluoride ions is comparable with that of other materials and in fact greater than certain adsorbents (Table 4). It is well known that the properties of an ion in a solution are determined mainly by ion-solvent and ion-ion interactions [42,43]. The molar Gibbs energy of the ion transfer from one medium to another, $\Delta_{\mathrm{t}} \mathrm{G}$, gives a comparison of the solvation of the ion in both media. Therefore, the capacity of any material for the extraction of anions changes significantly by changing the counter-ion. Therefore, the comparison must be done with materials for extraction of anions with the same counter ion. The amount of fluoride ions removed per unit mass by various adsorbents (in $\mathrm{mg} / \mathrm{g}$ ) is presented in Table 4 .

The higher capacity to remove fluoride anions from aqueous media by polypyrrole relative to calixpyrrole may be attributed to the availability of a larger number of active groups $(\mathrm{NH})$ on the surface of the former than that of calixpyrrole. On the other hand, the higher capacity of calixarene resins [44-47] relative to calixpyrrole may be attributed to the flexibility of the pendent arms (thiourea and amine).

Although materials reported in the literature for the uptake of fluoride anions, shown in Table 4, can effectively achieve fluoride concentration reduction, there is scope for improvement. The calixpyrrole receptor shows fast fluoride uptake and reasonable selectivity. In addition, calixpyrrole has many distinctive features over other materials reported in literature. Firstly, it interacts selectively with anions and as such the interference from other ionic species during the extraction process is negligible. Calixpyrrole is more selective for fluoride relative to chloride, bromide, iodide and dihydrogen phosphate anions by factors of $32,363,45$, and 684 and 16, respectively [26]. Secondly it is of low cost, easily prepared, shows comparable capacity level, and is a convenient, safe, simple, rapid and inexpensive method for the removal of fluoride anions from aqueous media.

\section{Conclusions}

The results of this study indicate that the calixpyrrole ligand is suitable for the development of an efficient system for the removal of fluoride ions from aqueous media. The uptake of F-anions by this ligand was influenced by experimental parameters such as initial anion salt concentrations, the amount of calixpyrrole, temperature and $\mathrm{pH}$. Lower $\mathrm{pH}$ and higher temperature ranges were found as the favorable conditions for maximum fluoride removal. 
The equilibrium adsorption behavior of fluoride anions by the calixpyrrole was found to obey the Langmuir adsorption isotherm. The mean free energy obtained from the D-R model indicated that, the removal of fluoride anions using the calixpyrrole was a chemical adsorption process. Modeling of sorption kinetics showed good agreement of experimental data with the pseudo second order kinetic model.

These results inspired us to polymerize the calixpyrrole receptor in order to enhance its capacity and at the same time retain its high selectivity toward fluoride anions. This work is still in progress and will be published once it is completed.

The study will contribute toward the remediation of fluoride polluted areas as well as in the various fields of materials science.

\section{Acknowledgements}

The authors gratefully acknowledge the financial and technical support of this work by Lebanese University and Prof. Angela Danil de Namor at University of Surrey.

\section{References}

[1]. Shen, F. X.; Gao, P.; Chen, G. Chem. Eng. Sci. 2003, 58, 987-993.

[2]. Grimaldo, M. V.; Ramirez, A. B. A.; Rosas, M.; Diaz-Barriga, F. Environ. Res. 1995, 68, 25-30.

[3]. Abe, I.; Iwasaki, S.; Tokimoto, T.; Kawasaki, N. J. Colloid Interface Sci. 2004, 275, 35-39.

[4]. Mahramanlioglu, M.; Kizilcikli, I.; Bicer, I. O. J. Fluorine Chem. 2002, 115, 41-47.

[5]. Maliyekkal, S. M.; Antony, K. R.; Pradeep, T. Sci. Total Environ. 2010, 408, 2273-2282

[6]. Karthikeyan, M.; Satheeshkumar, K. K.; Elango, K. P. J. Fluorine Chem. 2009, 130, 894-901.

[7]. Karthikeyan, M.; Satheeshkumar, K. K.; Elango, K. P. J. Hazard. Mater. 2009, 167, 300-305.

[8]. Karthikeyan, M.; Satheeshkumar, K. K.; Elango, K. P. J. Hazard. Mater. 2009, 163, 1026-1032.

[9]. Viswanathan, N.; Meenakshi, S. Appl. Clay Sci. 2010, 48, 607-611.

[10]. Gopal, V.; Elango, K. P. J. Hazard. Mater. 2007, 141, 98-105.

[11]. Danil de Namor, A. F.; Shehab, M. J. Phys. Chem. B 2003, 107, 64626468.

[12]. Danil de Namor, A. F.; Shehab, M. J. Phys. Chem. A 2004, 108, 73247330.

[13]. Danil de Namor, A. F.; Abbas, I.; Hammud, H. J. Phys. Chem. B 2006, $110,2142-2149$

[14]. Danil de Namor, A. F.; Shehab, M.; Abbas, I.; Withams, M. V.; Zvietcovich-Guerra, J. J. Phys. Chem. B 2006, 110, 12653-12659.

[15]. Danil de Namor A. F.; Shehab, M. J. Phys. Chem. B 2005, 109, $17440-$ 17444.

[16]. Danil de Namor, A. F.; Abbas, I.; Hammud, H. J. Phys. Chem. B 2007, 111, 3098-3105.

[17]. Atwood, J. L.; Davies, J. E. D.; Macnicol, D. D.; Vogtle, F.; Eds. Comprehensive Supramolecular Chemistry, Molecular Recognition Receptors for Cationic Guests, Vol. 1; Elsevier Science: Amsterdam, 1996.

[18]. Steed, J. W.; Atwood, J. L. Supramolecular Chemistry; Eds.; John Wiley \& Sons: Ltd.: Chichester, U. K., 2000.

[19]. Lehn, J. M.; Supramolecular Chemistry; VCH: New York, 1995.

[20]. Sessler, J. L.; Gale, P. A.; Genge, J. W. Chem. Eur. J. 1998, 6, 1095-1099.

[21]. Beer, D. P.; Gale, P. A. Coord. Chem. Rev. 1999, 185, 3-36.

[22]. Gale, P. A.; Anzenbacher, P.; Sessler, J. L. Coord. Chem. Rev. 2002, 222, 57-102.

[23]. Baeyer, A. Ber. Dtsch. Chem. Ges. 1886, 19, 2184-2185.

[24]. Aydogan, A.; Coady, D. J.; Lynch, V. M; Akar, A.; Marquez, M.; Bielawski, C. W.; Sessler, J. L. Angew. Chem. 2008, 120, 9794-9798.

[25]. Miyaji H.; Sessler, J. L. Supramol. Chem. 2001, 13, 661-669.

[26]. Danil de Namor, A. F.; Abbas, I.; in "Calixpyrrole-Fluoride Interactions: From Fundamental Research to Applications in the Environmental Field". Chapter of book entitled 'Advances in Fluorine Science', A. Tressaud (Ed.), Elsevier, Vol. 2, 2006.

[27]. Danil de Namor, A. F.; Khalife, R. J. Phys. Chem. B 2008, 112, 1576615770.

[28]. Nishiyabu, R.; Anzenbacher, Jr. P. Org. Lett. 2006, 8, 359-362.

[29]. Ganvir, V.; Das, K. J. Hazard. Mater. 2011, 185, 1287-1294.

[30]. Dubinin, M. M.; Radushkevich, L. V. Proceedings of the Academy of Sciences, Physical Chemistry Section, U. S. S. R. 55, 1947, 331-333.

[31]. Danil de Namor A. F.; Abbas, I. Anal. Methods 2010, 2, 63-71.

[32]. Sawalha, M. F.; Videa, J. R. P.; Gonzalez, J. R.; Gardea-Torresdey; J. L. J. Colloid. Interf. Sci. 2006, 300, 100-104.

[33]. Namasivayam C.; Yamuna, R. T. Chemosphere 1993, 30, 561-578.
[34]. Orhan, Y.; Buyukgungor, H. Water Sci. Technol. 1993, 28(2), 247-255.

[35]. Lagergren, S. Kungliga Svenska Vetenskapsakademiens, Handlingar 1898, 24, 1-39.

[36]. Ho, Y. S.; McKay, G. Process Saf. Environ. 1998, 76, 332-340.

[37]. Karthikeyan, M.; Satheesh Kumar, K. K.; Elango, K. P. Desalination 2011, 267, 49-56

[38]. Sathish, R. S.; Raju, N. S. R.; Raju, G. S.; NageswaraRao, G.; Kumar Janardhana, K. A. C. Sep. Sci. Technol. 2007, 42(4), 769-788.

[39]. Kamble, S. P.; Jagtap, S.; Labhsetwar, N. K.; Thakare, D.; Godfrey, S.; Devotta, S.; Rayalu, S. S. Chem. Eng. J. 2007, 129, 173-180.

[40]. Gupta, V. K.; Ali, I.; Saini; V. P. K. Water Res. 2007, 41, 3307-3316.

[41]. Aravind V.; Elango, K. P. Indian J. Chem. Technol. 2006, 13, 476-483.

[42]. Jeong, K. S.; Park, T. Y. Bull. Korean Chem. Soc. 1999, 20, 129-131.

[43]. Danil de Namor, A. F.; Pugliese, A.; Casal, A. R.; Llerena, M. B.; Aymonino, P. J.; Velarde, J. S. Phys. Chem. Chem. Phys. 2000, 2, 43554359.

[44]. Solangi, I. B.; Memon, S.; Bhanger, M. I. J. Hazard. Mater. 2009, 171 815-819.

[45]. Solangi, I. B.; Memon, S.; Bhanger, M. I. J. Hazard. Mater. 2010, 176, 186-192

[46]. Solangi, I. B.; Bhatti, A. A.; Kamboh, M. A.; Memon, S.; Bhanger, M. I. Desalination2011, 272, 98-106.

[47]. Solangi, I. B.; Bhatti, A. A.; Kamboh, M. A.; Memon, S.; Bhanger, M. I. Sep. Sci. Tech. 2011, 46, 1113-1120. 